Acta vet. scand. $1972,13,175-184$.

From the Department of Medicine I, Veterinary College of Norway, Oslo.

\title{
THE QUANTITATIVE DETERMINATION OF FIBRINOGEN IN NORMAL BOVINE PLASMA AND IN COWS WITH INFLAMMATORY CONDITIONS
}

By

Nils $E k$

\begin{abstract}
EK, NILS: The quantitative determination of fibrinogen in normal plasma and in cows with inflammatory conditions. Acta vet. scand. 1972, 13, 175-184. - A rapid method for the quantitative determination of fibrinogen in bovine plasma is described.

The method was employed in the determination of normal values in a material consisting of 100 cows and 50 calves and young animals of various ages. The mean value of the groups of cows was approximately $0.550 \mathrm{~g} / 100 \mathrm{ml}$. For young animals it was somewhat lower and for cows in the last month of gestation moderately higher than in the other groups.

The last part of the experiment involves the determination of the fibrinogen and $\gamma$-globulin levels in the plasma of 28 hospitalized cows with various inflammatory conditions. Group A in the material contained animals which were clinically cured and Group B animals that died or were killed.

Both groups showed a considerable increase in the fibrinogen level. In Group A the mean value fell back to approximately the normal range while in Group B it remained constantly elevated.

The sedimentation rate, $S R$, in human blood is primarily influenced by the fibrinogen content of the plasma. The SR in bovine blood is very low, and the test is therefore of little significance in diagnostic work. In conclusion, the possibility of using the fibrinogen determination in cattle for the same purpose as the SR in human blood is discussed.
\end{abstract}

fibrinogen; bovine plasma; inflammatory conditions.

An increase in fibrinogen values is found in human plasma in acute and chronic infections of various etiologies, in certain tumorous conditions, and during pregnancy (Schulz 1953).

The sedimentation rate, $S R$, in human blood is primarily dependent upon the fibrinogen content of the plasma but also 
upon other factors, including the content of immune globulins (Wuhrmann \& Märki 1963).

In bovine blood the $S R$ is very low after $1 \mathrm{hr}$. even in animals with active inflammatory diseases, and therefore this test is of little value in the diagnosis of disease in cattle (Schalm 1965). Analogous to the situation in man, however, an increased fibrinogen level has been demonstrated in the plasma of cattle in a number of inflammatory diseases where the resistance mechanism has been affected (Schacht 1962).

The first part of the present report involves an attempt to develop a practicable rapid method for quantitative fibrinogen determination in bovine plasma and by this method to determine normal values in animals of various ages and during pregnancy.

In the second part of the investigation the fibrinogen and $\gamma$-globulin concentrations in a number of cows with various inflammatory conditions were followed in an attempt to determine whether the fibrinogen determination in the plasma of cattle could serve the same purpose as the SR in human blood.

\section{METHODS}

The method used in this work for the determination of plasma fibrinogen was a simplification of that devised by Jacobson (1955). By diluting the fibrin clot in boiling $\mathrm{NaOH}$ instead of in urea solution, the process is much more rapid.

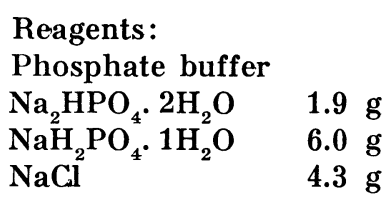

Aqua dest. ad $1000 \mathrm{ml}$

Thrombin

“Topostasin", Hoffman-LaRoche, Basel, Switzerland.

3000 i.u. dissolved in $10 \mathrm{ml}$ physiological saline and kept at $-20^{\circ}$.

Procedure:

The blood was taken from the jugular vein with pulverized EDTA as an anticoagulant, $20 \mathrm{mg}$ to $10 \mathrm{ml}$ blood.

In a beaker with a diameter of $25 \mathrm{~mm}, 1 \mathrm{ml}$ of plasma and $2 \mathrm{ml}$ of phosphate buffer were mixed, and $0.1 \mathrm{ml}$ of thrombin solution was added. The beaker was placed for $1 \mathrm{hr}$. at room temperature for coagulation. The clot was poured out on a pile of filter paper, the fibrin film was washed in $0.9 \% \mathrm{NaCl}$, rolled up on a glass rod and dried on filter paper according to the method described by Jacobson (1955). The fibrin film was then transferred to a graduate tube with 
$2 \mathrm{ml}$ of boiling $\mathrm{N}-\mathrm{NaOH}$ and placed in a boiling water bath for 2-3 min. The tube was then refilled to the $2 \mathrm{ml}$ mark, $8 \mathrm{ml}$ of $0.9 \% \mathrm{NaCl}$ was added, and the contents were carefully mixed. The optical density was read at $280 \mathrm{~m} \mu$ in the Beckman spectrophotometer DB against a blank containing the same amounts of $\mathrm{NaOH}$ and $\mathrm{NaCl}$.

All tests were carried out in duplicate. The standard deviation of the double tests was calculated by the formula $s=\sqrt{\frac{\Sigma d^{2}}{2 n}}$, where $d$ is the difference between the double tests and $n$ the number of double tests. The standard deviation in the material in the first experiment was 0.009 , and in the material in the second experiment 0.014 .

In order to evaluate the method 20 double tests were performed, using the Micro-Kjeldal method. The Micro-Kjeldal method was implemented by transferring the fibrin roll to the Kjeldal-flask with $4 \mathrm{ml} \mathrm{H}_{2} \mathrm{SO}_{4}$ half-concentrated, and the nitrogen content was determined according to the method described by Hawk (1965).

On a diagram with the values obtained by the Micro-Kjeldal method plotted along the abscissa and the corresponding values for the optical density on the ordinate, the 20 points lay assembled around a straight line in accordance with Beer-Lambert's Law. The correlation coefficient between the values from the two methods was 0.846. The factor for the conversion of the optical density to gram \% fibrinogen by the described method was calculated to 0.61 .

The $\gamma$-globulin percentage in the serum was determined by the method described by $E k$ (1969), and the determination of the total protein in serum was arrived at with a refractometer according to the method of Dimopoullos (1963).

\section{Experiment 1}

\section{MATERIAL}

The material includes plasma from 100 normal cows of the NRF breed, age $>2 \frac{1}{2}$ years, and from 50 normal calves and young animals of the same breed, both sexes, and ages from 0 to $2 \frac{1}{2}$ years.

\section{Experiment 2}

In this experiment 28 cows, admitted to the Department of Medicine I with various inflammatory conditions, were used. The animals were tested several times at different periods during hospitalization.

\section{Experiment 1}

Table 1 shows the fibrinogen concentration in the plasma of normal cows and calves of various ages and of animals in the last month of pregnancy. Very young calves have the lowest value. The mean values increase up to the age of $2 \frac{1}{2}$ years. After 
T a ble 1. Fibrinogen in normal plasma from cattle $(\mathrm{g} / 100 \mathrm{ml})$.

\begin{tabular}{|c|c|c|c|c|c|c|c|}
\hline \multicolumn{4}{|c|}{ Animals } & \multirow{2}{*}{$\begin{array}{c}\begin{array}{c}\text { Num- } \\
\text { ber }\end{array} \\
20\end{array}$} & \multirow{2}{*}{$\begin{array}{c}\begin{array}{c}\text { Mean } \\
\text { value }\end{array} \\
0.445\end{array}$} & \multirow{2}{*}{$\begin{array}{c}\text { Range } \\
0.614-0.353\end{array}$} & \multirow{2}{*}{$\begin{array}{r}\begin{array}{r}\text { Standard } \\
\text { deviation }\end{array} \\
0.074\end{array}$} \\
\hline calves & age & $0-2$ & months & & & & \\
\hline , & , & $2-12$ & , & 16 & 0.470 & $0.663-0.397$ & 0.111 \\
\hline young cattle & & $12-28$ & , & 14 & 0.502 & $0.702-0.384$ & 0.089 \\
\hline cows & & $2 \frac{1}{2}-4$ & years & 35 & 0.552 & $0.781-0.350$ & 0.127 \\
\hline 年 & & $5-8$ & 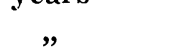 & 40 & 0.555 & $0.658-0.347$ & 0.113 \\
\hline in the & last & month of & pregnancy & 25 & 0.585 & $0.861-0.433$ & 0.115 \\
\hline
\end{tabular}

that age there is no noticeable difference between the age groups. In man a definite age dependency, in the form of rising fibrinogen levels correlated with increasing age, has been demonstrated (Schulz 1953).

From Table 1 it can be seen that cows in the last month of gestation had a moderate rise in the fibrinogen level in comparison with the other animals.

\section{Experiment 2}

The results of the clinical material are divided into two groups. Group A includes the animals which by clinical observation appeared to be cured and Group $B$ the animals which died or were killed due to incurable disease.

Table 2. Fibrinogen in plasma from 28 hospitalized cows with infectious conditions $(\mathrm{g} / 100 \mathrm{ml})$.

\begin{tabular}{lccccc}
\hline & \multicolumn{2}{c}{$\begin{array}{c}\text { Group A } \\
\text { cured animals }\end{array}$} & & \multicolumn{2}{c}{$\begin{array}{c}\text { Group B } \\
\text { dead or killed } \\
\text { during the hospitalization }\end{array}$} \\
\cline { 2 - 4 } & highest value & lowest value & & highest value & lowest value \\
\hline Number of animals & 16 & 16 & & 12 & 12 \\
Range & $1.581-0.725$ & $1.132-0.388$ & & $2.449-1.172$ & $1.550-0.577$ \\
Mean value & 1.342 & 0.614 & & 1.480 & 1.033 \\
Standard deviation & 0.394 & 0.164 & & 0.566 & 0.392 \\
\hline
\end{tabular}

Table 2 shows the average figures for the highest and lowest fibrinogen values in the two groups during the observation period. In both groups the highest fibrinogen value was considerably above the normal range, but the highest figure appeared 
in Group B. There is a marked difference in the lowest fibrinogen values in the two groups. In Group $A$ this value lies within the normal range, while in Group $B$ it reaches a considerably higher level.

Figs. 1 and 2 show the fibrinogen and $\gamma$-globulin concentration during the observation period in three selected individuals from each group. There is a marked difference in the pattern of

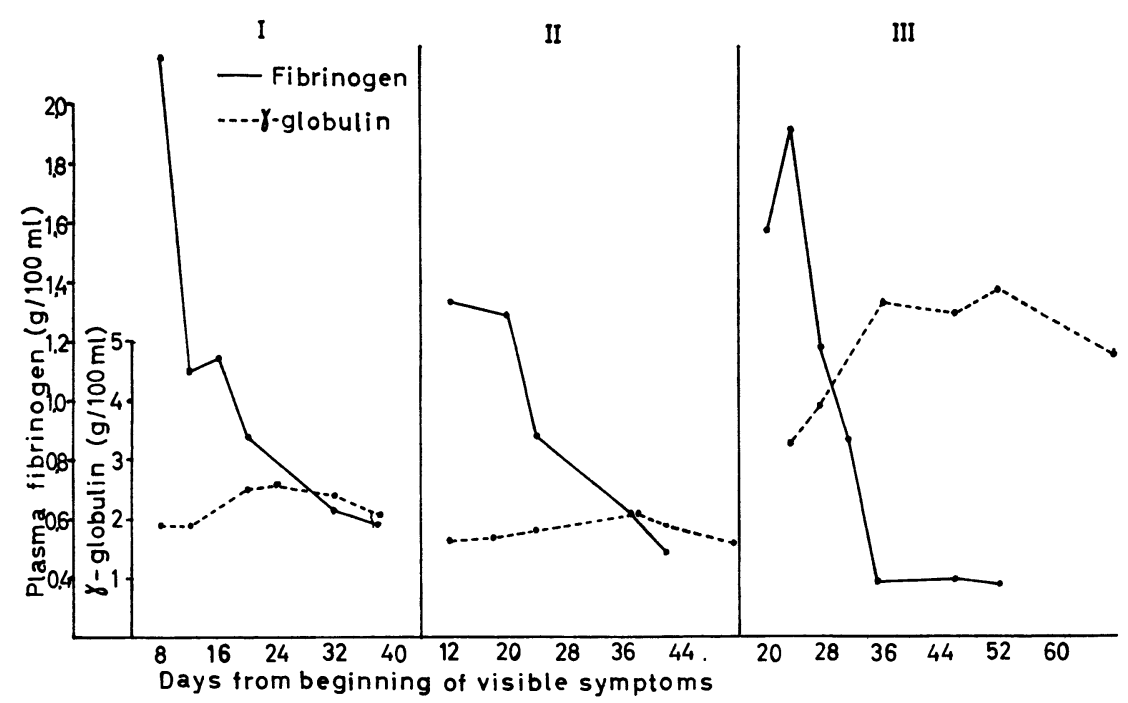

F i g u r e 1. Fibrinogen in plasma and $\gamma$-globulin in serum from three cows in Group A Table 2.

I: J.no. 75/70. Cow, NRF, 6 years. Coli mastitis with paresis. Hospitalization 30 days. Cured.

II: J.no. 66/70. Cow, NRF, 5 years. Traumatic reticulo-peritonitis. Laparotomy. Hospitalization 40 days. Cured.

III: J.no. 65/70. Heifer, NRF, $1 \frac{1}{2}$ years. Traumatic indigestion with diaphragm abscess. Laparotomy. Hospitalization 40 days. Cured.

the fibrinogen curves in the two groups. In Fig. 1 the curves gradually drop from a high initial level to an almost normal level, but in Fig. 2 they remain at a high level.

The $\gamma$-globulin level varies greatly in the six animals. It was considerably elevated in patients III, IV, and VI. The curves in Fig. 1 rose evenly during the first part of the period toward a maximal point and then gradually fell back towards the starting level. Fig. 3 shows the electrophoresis pattern of serum from patient III 35 days after the onset of symptoms, when $\gamma$-globulin 


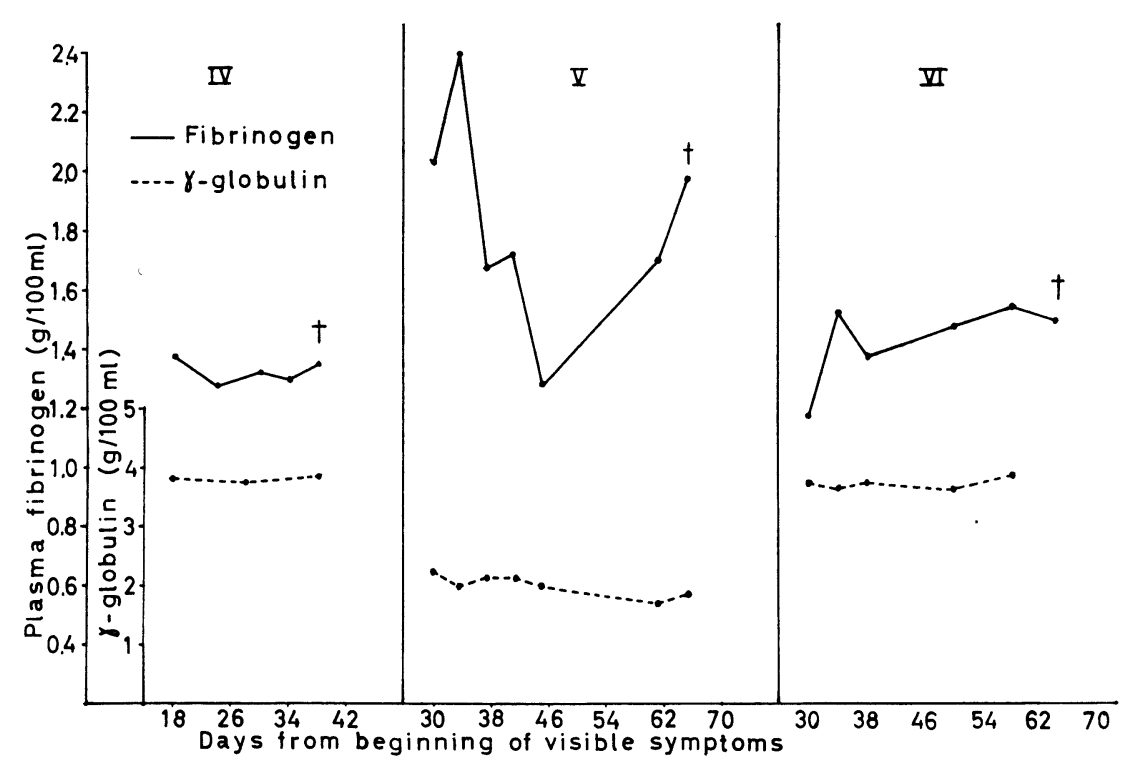

F i g u r e 2. Fibrinogen in plasma and $\gamma$-globulin in serum from three cows in Group B Table 2.

IV: J.no. 37/70. Cow, NRF, 3 years. Muscle necrosis with multiple abscesses and pyaemia. Hospitalization 25 days. Killed in moribund condition. Necropsy: Decubitus with formation of abscesses. Endocarditis tromboticans.

V: J.no. 69/70. Cow, NRF, 6 years. Traumatic indigestion with pyaemia. Hospitalization 45 days. Killed in moribund condition. Necropsy: Splenitis, hepatitis et bronchopneumonia apostematosa. Endocarditis fibrinosa.

VI: J.no. 280/70. Cow, NRF, 4 years. Peritonitis consequent to laparotomy. Hospitalization 32 days. Killed. Necropsy: Peritonitis fibrinosa.

amounted to $60.1 \%$ of the total protein value. The $\gamma$-globulin seems to react much more slowly to inflammatory precursors than the fibrinogen.

\section{DISCUSSION}

The normal values found in this experiment indicate that the fibrinogen level in cattle is not dependent on age to the same extent as in man. The young calves show a somewhat lower value than the other animals. The level seems to increase up to the age of $2 \frac{1}{2}$ years. About that time most heifers have their first 


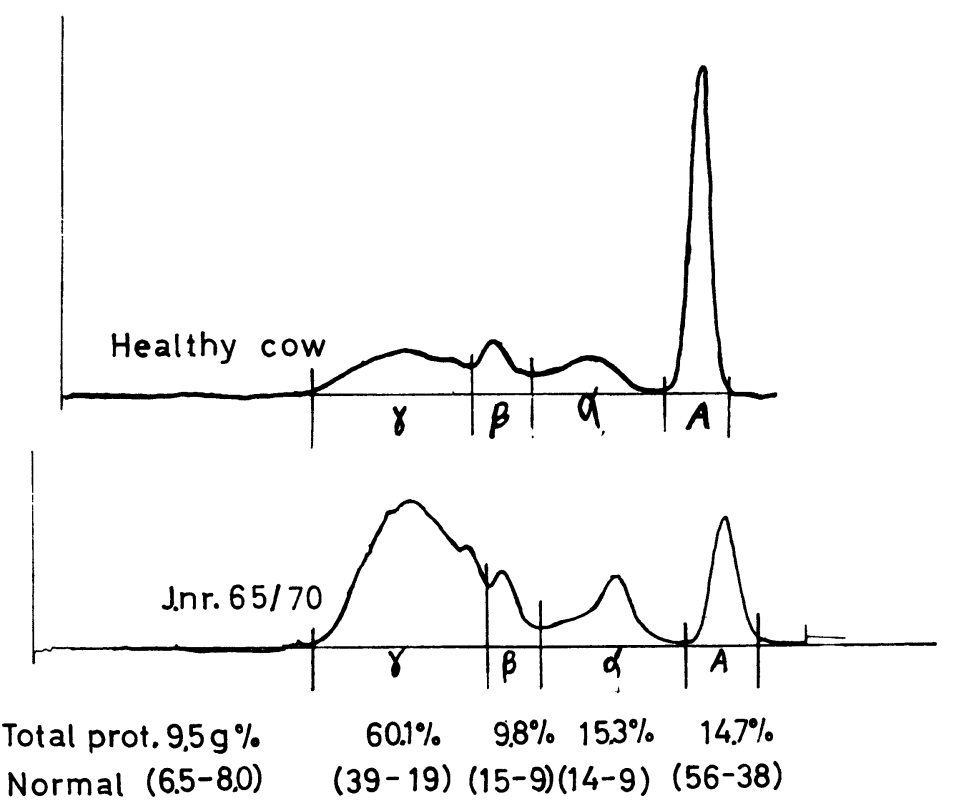

Figur e 3. Scanned serum proteins of cellulose acetate membrane from patient III 35 days after the onset of symptoms compared with correspondent scan from a healthy cow.

parturition. In cows older than $2 \frac{1}{2}$ years there seems to be no age dependency. Fritzsche (1959) and Messow (1959) found significantly higher fibrinogen values in adult cattle in comparison to calves, while Wehmeyer (1954a) found that age had no influence on the fibrinogen level.

The rise in the fibrinogen level in the last month of pregnancy found here is much less marked than in women, where the rise is from $250-300 \mathrm{mg} / 100 \mathrm{ml}$ up to $500 \mathrm{mg} / 100 \mathrm{ml}$ (H jort 1956).

Messow found that the feed and management of the animals did not have any influence on the fibrinogen concentration, and Wehmeyer (1954b) found small daily fluctuations and moderate variations in the course of both one month and one year in the same normal animal. The values in Table 1 might therefore be considered as normal values for cattle under various types of management.

The second experiment showed a general and considerable rise in the fibrinogen level in plasma of cows with inflammatory conditions, corresponding to what has been observed in man. In a number of cases the rise was very high as seen in Figs. 1 
and 2. Schacht (1962), observing a similar material, found some very high fibrinogen values, which were attributed to the sort of fibrinous inflammation that occurs in cattle.

The results of the second experiment reflect a definite difference in the fibrinogen level of the two groups of patients. The investigation indicates that the fibrinogen determination in cattle is valuable for the purpose of diagnosing inflammatory conditions, and that regular charting of the fibrinogen curve during the course of the disease may serve a valuable prognostic function.

The $\gamma$-globulin level seems to react much more slowly and is relatively less effected by changes in the extent of the inflammation than is fibrinogen.

It must be noted that this work involved a limited number of animals. The investigation should be carried out on a larger material before any definite conclusions can be drawn.

In human medicine the SR is employed routinely and extensively as a clinical diagnostic test. Parallel with an increased fibronogen content an aggregation of red blood cells often occurs which again is reflected in an increased SR (Thorsén \& Hint 1950). Since SR is of little use in cattle, fibronogen determination in plasma seems to be a good substitute in this animal species.

The method employed here can be performed quickly and must be considered as speedier than the most common laboratory methods (Jacobson 1955, Blombäck \& Blombäck 1956). The small standard deviations recorded for duplicate tests indicate a satisfactory degree of accuracy.

The method should therefore be practicable for routine use in clinical laboratory diagnosis and thereby supplement the other haematological tests.

\section{ACKNOWLEDGEMENT}

The author wishes to thank Dr.med. U. Abildgaard, Medicine Dept. A, Aker Hospital, Oslo, Norway, for valuable advice and guidance during the experiment.

\section{REFERENCES}

Blombäck, B. \& M. Blombäck: Purification of human and bovine fibronogen. Ark. Kemi 1956, 10, 415-425.

Dimopoullos, G. T.: Clinical Biochemistry of Domestic Animals. Acad. Press, New York and London 1963. 
$E k, N .:$ Studies on electrophoresis on cellulose acetate membrane of bovine serum proteins in healthy animals. Acta vet. scand. $1969,10,118-126$.

Fritzsche, G.: Vergleichende gravimetrische Untersuchungen über den Blutfibrinogengehalt beim Rind, Kalb, Hund und Schwein. (Comparative gravimetric investigations in the blood content of fibrinogen by the cattle, calf, dog and pig). Thesis, Berlin 1959.

Hawk, P. B.: Physiological Chemistry. ed. Bernhard L. Oser. Mc Graw-Hill Book Company, New York 1965, 14th Ed. p. 1219.

Hjort, P.: Akutt fibrinogen-mangel i svangerskapet. (Acute fibrinogenopenia in pregnancy). T. norske Lægeforen. 1956, 76, 756760.

Jacobson, K.: Studies on the determination of fibrinogen in human blood plasma. Scand. J. clin. Lab. Invest. 1955, Suppl. 14.

Messow, C.: Fibrinogen und Fibrinolyse (Neue Erkenntnisse bei der Entzündung). (Fibrinogen and fibrinolysis - new knowledges about inflammation). Dtsch. tierärztl. Wsch. 1959, 66, 401-406.

Schacht, P.: Untersuchungen über den Fibrinogengehalt im Blut bei inneren Erkrankungen des Rindes. (Investigations in the blood content of fibrinogen by cattle suffering from internal diseases). Thesis, Hannover 1962.

Schalm, O. W.: Veterinary Hematology. Lea \& Febiger, Philadelphia 1965.

Schulz, F. H.: Das Fibrinogen. Verlag Georg Thieme, Leipzig 1953.

Thorsén, G. \& H. Hint: Aggregation, sedimentation and intravascular sludging of erythrocytes. Acta chir. scand. 1950, Suppl. 154.

Wehmeyer, P.: Concentration of plasma proteins in the ox. I. Individual differences. Nord. Vet.-Med. 1954 a, 6, 717-736.

Wehmeyer, P.: Concentration of plasma proteins in the ox. II. Variation in composition of the blood in the individual animals. Nord. Vet.-Med. 1954 b, 6, 818-824.

Wuhrmann, F. \& H. H. Märki: Dysproteinämien und Paraproteinämien. (Dysproteinemias and paraproteinemias). Verlag Schwabe \& Co, Basel 1963.

\section{SAMMENDRAG}

Kvantitativ fibrinogenbestemmelse $i$ bovint normalplasma og hos kyr med infeksiфse prosesser.

Det beskrives en hurtigmetode til kvantitativ fibrinogenbestemmelse i bovint plasma.

Metoden er anvendt for bestemmelse av normalverdier på et materiale bestående af 100 kuer og 50 kalver og ungdyr på forskjellige alderstrinn. Middelverdien hos voksne kyr lå omkring 0,550 g/100 ml. Helt unge kalver og ungdyr lå noe lavere og kyr i siste drektighetsmåned moderat høyere enn de фvrige grupper. 
Siste del av fors $\varnothing$ ket omfatter bestemmelse av fibrinogen og $\gamma$-globulinnivå i plasma hos 28 hospitaliserte kyr med forskjellige infeksiøse prosesser. Gruppe A i materialet inneholdt dyr som klinisk ble restituert og gruppe B dyr som døde eller ble.avlivet.

Begge grupper hadde en betydelig stigning $\mathrm{i}$ fibrinogenverdien. I gruppe A sank middelverdien til omkring normalområdet mens den i gruppe B stadig var forh $\varnothing$ yet.

Senkningsreaksjon, SR, i humant blod er først og fremst påvirket av plasmaets fibrinogeninnhold. SR i bovint blod er meget liten og prøven derfor av liten betydning i diagnostikken. Sluttelig blir diskutert om fibrinogenbestemmelse hos storfe kan anvendes i samme $\varnothing$ yemed som SR i humant blod.

\section{(Received March 22, 1971).}

Reprints may be requested from: Nils Ek, Department of Medicine I, Veterinary College of Norway, Postboks 8146, Oslo Dep., Oslo 1, Norway. 